\title{
Usury Laws: Harmful When Effective
}

\author{
NORMAN N. BOWSHER
}

OST INTEREST rates have risen to historically high levels in recent months. This development, in view of present law, has caused serious problems to develop in the credit markets because in most jurisdictions usury restrictions on the payment of interest have generally remained at previously established lower levels. The consequence of this has been that borrowers who are willing to pay the competitive rate for funds often find that they are legally mable to obtain financing. As a result, they are faced with the choice of either cirommenting the law to obtain the desired funds or losing out to other borrowers who may not be willing to bid as much, but who are legally able to contract because of the nonuniformity of usury laws.

Despite the credit market distortions caused by ceilings on interest rates, usury laws have been retained in most jurisdictions. It is the intent of this article to provide some insight and perspective on the value of such restrictions by reviewing briefly the history and justification of such laws, the role of interest rates, and some of the effects of interest rate restrictions. ${ }^{*}$

\section{Her of sem}

Usury laws have been traced back to the dawn of recorded history. Both legal and religious restrictions on interest charges were imposed in ancient times. ${ }^{2}$ The early Babylonians permitted credit but limited the rate of interest. One of the earliest writings of the

1 Previous discussions of interest rate controls were given by Clifton B. Luttrell, "Interest Rate Controls - Perspective, Purpose, and Problems," his Review (September 1968), pp. 6-14, and Charlotfe E. Ruebling, "the Administration of Regulation $Q, "$ this Review (February 1970), pp. 29-40.

2See Sidney Homer, A History of Interest Rates (New Brumswick, New Jersey: Rutgers University Press, 1963).
Bible (Deuteronomy 23:19-20) stated, "Thou shalt not lend upon usury to thy brother, ... Unto a stranger thou mayest lend upon usury; but unto thy brother thou shalt not lend upon usury...." In the New Testament (Luke 6:35) the admonition was broadened ". . . lend freely, hoping nothing thereby."

In Greece, Aristotle considered money to be sterile, and that the breeding of money from money was umnatural and justly hated. During the period of the Roman Republic, interest charges were forbidden, but they were permitted during the time of the Roman Empire.

During the early Middle Ages religious leaders treated the subject more thoroughly, and reached the same conclusion - that interest on loans was unjust. The exploitation of the poverty-stricken by rich and powerful creditors who lent money at interest was considered sinful to the Christians of that period, who stressed humility and charity as among the greatest virtues and played down the value of earthly goods. Secular legislation responded to the Church's influence and, in general, interest charges and usury were regarded as synonymous. ${ }^{3}$

The increase in economic activity and expansion of personal freedom that came with the Renaissance forced modifications in the prevailing views concerning interest rates. Recognizing that man was imper. fect, Martin Luther and other 15 th century reformers began to concede that creditors could not be prevented from charging interest. In the 16 th century John Calvin rejected the scriptural basis for interest prohibition on grounds of conflicting interpretations and changed circumstances, but still advocated some

\footnotetext{
BEugene von Bohm-Bawerk, Gapital and Interest, trans. George Huncke and Hans Semholz (South Holland, Illinois: Libertarian Press, 1959 ), pp. 13-24.
} 
control. Turgot, an 18th century French economist, claimed that money was the equivalent of land, and hence the owner should not be inclined to loan his money unless he could expect a return as great as he would obtain through the purchase of land."

Legal restrictions on the payment of interest were generally relaxed in the 18 th century, but the belief continued that the people who needed to borrow funds should be protected against overly high charges. Consequently, most nations maintained legal maximum usury rates at "reasonable" levels.

Usury laws in the United States were inherited, in large part, from the British in colonial days. While these laws generally remain in force in the United States, Great Britain, after intense pressure in the early 19 th century, repealed these and other restrictions on commerce and trade in $1854 .^{5}$

One factor complicating attempts to maintain interest rate ceilings arose from the fact that risks and administrative expenses in making very small loans were often so great that legitimate dealers could not handle such advances with prevailing rate ceilings. This situation fostered illegitimate loan "sharks" with exorbitant interest charges. As a result, it was eventually recognized that higher rates should be permitted on small loans, and the small loan laws emerged.

\section{Arement}

As noted, ethical and religious arguments have been relied on to a great extent to justify either the prohibition or limitation of interest payments. Another factor which has been instrumental in sustaining support for usury laws has been public opinion which generally viewed the small borrower as an underdog at the mercy of large well-financed institutions. As a consequence of this public attitude, legislators have been reluctant to raise or eliminate interest rate ceilings.

Several economic argtments also have been advanced to justify usury laws, and these considerations tend to bolster the moral and political reluctance to raise rate ceilings. The first of these arguments asserts that whereas most lenders are knowledgeable about conditions in the particular credit market in which they operate, it is readily observable that a sizable number of borrowers are unsophisticated and naive. It is contended that these borrowers are concerned only with obtaining credit and do not even know what

4 lbid, pp. 25-60.

"Homer, A History of Interest Rates, p. 187. rate of interest they are paying. Furthermore, relatively few make a serious effort to study conditions or to shop around for better terms or better timing. Finally it is argued that contracts made with such unknowing borrowers at rates above those existing in the market for similar types of loans represent a distortion of competitive forces and provide a windfall to lenders.

A similar argument for the regulation of interest rates is related to the comparative market power of borrowers and lenders. Since lenders are usually fewer in number and larger in resources than borrowers, it is contended that they have market power which can be used to command artificially high rates. Hence, usury laws provide competitive balance between the two groups.

Another argument for interest rate regulation is concerned with the impact of lower interest rates on the economy. It has been contended that low interest rates are desirable to encourage more investment and consumption and promote faster economic growth.

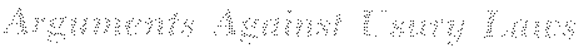

Those who oppose interest rate restrictions view credit markets as relatively efficient when left alone to operate freely. According to this position free competitive markets lead to an optimum allocation of resources and maximum individual satisfaction. Consequently, interferences with normal credit flows, by use of imposed ceilings on lending or deposit rates, can only create inefficiencies in financial markets which hamper production and exert an adverse influence on the distribution of goods and services.

It has been charged that maximum loan rates are necessary because credit applicants are gullible and would enter into oppressive contracts without such protection. But, are not individuals just as likely to be gullible in their dealings in other markets? Why then is the credit market singled out as an area to promulgate legal restrictions against such oppressive contracts? More importantly, has this special attention had its intended effects? That is, can and do these laws protect the uninformed from exploitation, and can the benefits of this protection be justified in view of the attendant social costs? Existing imperfections in credit markets could probably be reduced to a greater extent and with less cost by fostering greater competition among lenders. Also, education and counseling of borrowers may be a more efficient method to improve their performance than imposing rigid ceilings. 
In most credit markets competiton is very keen. Major lenders include commercial banks, savings and loan associations, insurance companies, mutual savings banks, mortgage companies, sales finance companies, personal finance companies, credit unions, real estate investment trusts, farm credit agencies, retailers, and individuals. It is relatively easy to establish a business for lending funds, except for restrictions imposed by the Government. In most cases where competition is lacking in a given market, it has resulted from legal limitations on entry or activities. In practice, competitive forces have kept most market interest rates below usury ceilings for most of the past forty years.

For a brief period, artificially holding interest rates down probably does stimulate investment and contribute to economic expansion. However, maintaining arbitrarily low rates by imposing ceilings discourages saving at the same time that it stimulates investment demand, placing upward pressure on interest rates. As a result, rates can only be maintained at the lower level by some form of nonprice rationing (which tends to reduce efficiency and offset, in the longer run, the sought-after investment increases) or by the creation of money and credit at progressively faster rates (which contributes to accelerating inflation).

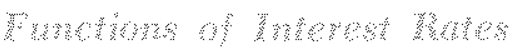

Interest rates play a strategic role in the economy. Interest rates are prices, and, as is true of all prices, they serve a rationing function. They are the prices that allocate available funds, and hence command over resources, among competing uses. Normally, the term "interest rate" is used in reference to the return on marketable securities or a loan of funds. However, the concept of "interest rate" can be applied to all goods. The rate of interest reflects the price of the convenience of earlier availability, the preference for more certain rather than less certain consumption rights, and the economy's ability to use resources to increase output.

To the borrower, interest rates represent a cost, and as such, influence investment and consumption decisions. To the saver, they represent a return and affect decisions regarding the amount to be saved. To wealth holders and managers of funds, interest rates or yields are a common denominator for evaluating alternative forms of holding wealth and alternative avenues for placing funds.

At any time, some individuals or businesses find that with their incomes, tastes, and investment pros- pects it is not desirable to pay the going rate for funds. They are "priced out of the market," just as there are those who find that at current prices it is not expedient to hire a servant, eat steak, or purchase a luxury automobile. Any movement in interest rates (as with other prices) will cause a reevaluation of projects which require the borrowing of funds.

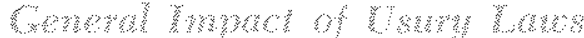

Throughout most of the period since the 1920s, usury laws have been ineffective because the interest ceilings were at levels above prevailing market rates. However, with the rise in inflation, and consequently interest rates, since the mid-1960s, usury laws have had a significant impact on many credit markets. Their effects have been quite arbitrary and have weighed heaviest on those credit seekers generally considered most risky.

Professor Roger Miller contends that usury legislation often adversely affects the ones it is designed to protect. ${ }^{6} \mathrm{He}$ illustrates this conclusion by citing the Washington state experience, where consumer loans from credit card companies were generally at an annual rate of 18 percent. Consumer advocates felt that this rate was much too high, and that poor people would be aided by a lower charge. In 1968, the maximum rate was lowered by referendum to 12 percent. However, at the lower rate the amount of credit demanded exceeded the amount supplied, and the people with the weakest credit worthiness were the ones denied credit at 12 percent. Welfare mothers, people with records of unstable employment, students, and the elderly fell into this category. Gainers from the reduced rates were the ones who had the most wealth, best jobs, and the highest probability of being able to repay the loan.

Sometimes those higher risk borrowers, who are refused credit from legitimate lenders because of usury laws, seek funds from loan sharks who ignore the legislated ceilings. Costs of operating outside the law are relatively high, and competition among such unscrupulous lenders is severely limited; hence, some interest rates may be several times the level that would have existed in the absence of ceilings. ${ }^{i}$

As market rates approach usury ceilings, venture or developmental credit, which of course contains a higher than average degree of risk, becomes limited.

\footnotetext{
GRoger L. Miller, Economics Today (San Francisco: Canfeld Press, 1973), pp. 244-250.

TJohn M. Seidl, "Let's Compete with Loan Sharks" Harvard Business Retiew (May-June 1970), pp. 69-77.
} 
Since such credit can only be extended by lenders at a higher rate of interest to compensate for the additional risk involved, these loans are among the first to be affected as market rates rise relative to usury ceilings. Without such venture capital, the entrepreneur is frustrated, and economic progress and growth is hampered. ${ }^{8}$

By contrast, the volume of credit flowing to wealthy individuals and sound established businesses may be as great or greater under severe usury restrictions as under free market conditions. ${ }^{9}$ Since low usury maximums prevent other individuals and firms from effectively competing for funds, a greater share of the available funds tends to flow to lower risk applicants. The anticompetitive effects of these laws are thus spread from credit to product markets.

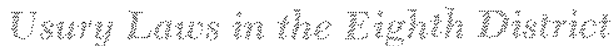

In general, usury laws tend to be more restrictive in the central section of the country than in states on or near either coast. In several Eighth District states usury laws have been a major obstacle in credit markets. In Illinois and Missouri the current general usury ceiling is a very low 8 percent, and in Kentucky the ceiling is 8.5 percent. In each of these states, however, exemptions from the ceiling exist, such as for corporations. Despite the exemptions, many credit Hows have been interrupted because of the ceilings, particularly away from potential individual borrowers.

Arkansas, Mississippi, and Tennessee have somewhat higher usury ceilings -10 percent in each case. However, because of the lack of legal exemptions from the maximums in Arkansas and Tennessee, the ceilings have been causing substantial disruptions to borrowers, lenders, and the general economy of these states. This has been particularly noticeable since April when the prime rate on business loans nationally climbed above 10 percent. During May and June of this year, commercial and industrial loans declined 9.3 percent at weekly reporting banks in Memphis and Little Rock, while they were rising 2.8 percent at all weekly reporting banks in the nation. In the cor-

\footnotetext{
SStudies show that in those states permitting higher rates, lenders tend to expand credit opportmities. Lenders appear more willing to accept higher risk of losses if the rate is sufficient to compensate for bad deht, investigation, and collection expenses. Maurice B. Goudzwaard, "Price Ceilings and Credil Rationing," Joumal of Finance (March 1968), pp. 183-184.

This may not always be the case, becuse the total volume of loanable funds is likely to be smaller under severe interest rate ceilings. Saving is disconraged relative to consumption and funds tend to flow out of the jurisdiction or directy from savers into venture capital.
}

responding period last year, when market rates were below the ceilings, these loans changed little in Memphis and Little Rock and rose 2.9 percent nationally.

In an effort to alleviate hardship, the ceiling in Mississippi was raised to 10 percent from the extremely restrictive 8 percent level, effective July 1, 1974. In Illinois, the ceiling for residential loans was raised on July 12, 1974 from 8 percent to 9.5 percent for the period until July 1, 1975. Among Eighth District states, only Indiana has had credit markets relatively free from usury restrictions.

Quantitative measures of the volume of potential loans affected by the rate restrictions are not available, but comments from market participants indicate that it is sizable. The following sketchy, indirect evidence also indicates that the impact has been great.

In the first four months of this year, the average interest rate on FHA 30-year mortgages was 8.78 percent nationally; in the corresponding period last year the rate was 7.62 percent. Two District states had usury laws applicable to home mortgages that were between these rates - Mississippi and Missouri at 8 percent. In these two states residential construction contracts fell 34 percent from the first four months last year to the comparable period this year, according to F, W. Dodge data. In Arkansas, Indiana, and Tennessee, which had 10 percent or higher usury ceilings, and Kentucky and Illinois, which exempted certain residences from the ceilings, residential contracts declined 16 percent. The average decrease for the nation was 21 percent over the same period.

By contrast, contracts for nonresidential construction, which are frequently exempted from ustry ceilings, rose 8 percent in Mississippi and Missouri from the first four months last year to the first four months this year. This was about the same as the 9 percent gain in Arkansas, Illinois, Indiana, Tennessee and Kentucky and greater than the 2 percent nationally in the same period.

Insured savings and loan associations in Missouri had a 74 percent smaller increase in savings "deposits" in April and May this year than they did in the corresponding months last year. Nevertheless, these associations purchased 10 percent more mortgages in the two months this year when the national market rate on mortgages was above the state's usury ceiling than in the like period last year when the market rate was below the ceiling. This seemingly contradictory development can be explained by noting that the bulk of these purchases were from states where the 


\title{
STATE USURY LAWS
}

\author{
State \\ Alabana \\ Alaska \\ Arizono \\ Basic Rate \\ $8 \%$ \\ $12 \%$ \\ $10 \%$ \\ Some Majar Exceptions \\ Far individuals, firms, partnerships, associations, and non-profit organizations the rate is $8 \%$ on loans \\ to $\$ 100,000$ and $15 \%$ on loans above that. These same groups moy agree to pay more than $15 \%$ \\ on loons greater than $\$ 100,000$. For corpotations the maximum rate is $8 \%$ on loon $\$ 0$ \$10,000, \\ $15 \%$ on loans between $\$ 10,000$ to $\$ 100,000$ and no ceiling on loons above $\$ 100,000$ \\ Twelve-and-oneholf percent is the rate on real astate contracts. \\ Eighteen percent is the celling for loans over $\$ 5000$ to corporations.
}

Arkafisas

California

Colorado

Connecticut

Delaware

District of Cotumbio

Forida

Georgia

Hawaii

Idaho

Hetinois

Fndiand

lowo

Karasos

Kentucky

Louisiana

Maine

Moryland

Massachusefts

Michigon

Minnesoto

Mississippi

Missouri

Montana

Mebraska
$10 \%$

$10 \%$

$12 \%$

$12 \%$

$9 \%$

$8 \%$

$10 \%$

$8 \%$

$12 \%$

$10 \%$

$8 \%$

$18 \%$

$9 \%$

$10 \%$

$81 / 2 \%$

None

Sovings and loan ossociations, industrial loan companies, banks, credit unions, and agricultural assockations are exempt from the usury law.

The maximum charge on non-supervised consumer loans is $12 \%$. On supervised loons, except for re volving loans, the maximum rate is the greater of $18 \%$ on all unpaid batances; of a totat of $36 \%$ on unpoid balances of $\$ 300$ or tess, $21 \%$ on unpaid balances over $\$ 300$ and not over $\$ 1000$; and $15 \%$ on unpaid balances over $\$ 1000$. The maximum rate on consumer reloted loans is $18 \%$, an revolving loans $12 \%$, and all other loans $45 \%$.

The ceiling rate on loans to corporations in excess of $\$ 10,000$ is $18 \%$. The $12 \%$ ceiling does not apply to any loan mode by any national or state bank or savings \& loan, to any mortgage on real property in excess of $\$ 5,000$, or mode pursuant to a revolving loan agreement on which the tolal principal amount owing is more than $\$ 10,000$. loans secured by geal estate only through written agreement.

Also the ceiling rate may be exceeded an loans guaranteed under the Mationol Housing Act or by the VA are exempt.

The ceiling is $15 \%$ for corporate loons and all other lodans above $\$ 500,000$.

No ceting applies on loans above $\$ 2500$ to corporations and on loars above $\$ 100,000$ to individuals. Lans secured by realty may carry a rate of up to $9 \%$.

The maximum rate on non-supervised consumer loans is $18 \%$ and on revolving loans $15 \%$. Supervised loans carry a maximum rate of $18 \%$ on all unpaid balances, or a total of $36 \%$ on unpaid balances ot $\$ 390$ or less, $21 \%$ on unpaid balances between $\$ 390$ and $\$ 1300$, and $15 \%$ on unpaid balances over $\$ 1300$. A celling of $12 \%$ applies to loans of over $\$ 10,000$ to corporations. Firms engaged in agriculture may be required to pay a maximum of only $10 \%$ on loans.

All corporate loans and business loans to non-profit organizations; as well as mortgage loons insared by the FHA or guatanteed by the VA may be contracted fot at any rate. Also secured loans greater than $\$ 5000$ may be at any rate. Effective 1 uly 12,1974 the maximum interest rate that may be charged on loans secured by residential reat estate and entered into betore July 1, 1975 was raised to $91 / 2 \%$.

moximum rate of $18 \%$ applies to non-supervised consumef loans consumer reloted loans and revalving loans. Supervised loans carry a maximum rate of the greater of $18 \%$ on all unpaid balances. or a tolal of $36 \%$ on unpoid balances of $\$ 300$ or tess, $21 \%$ on unpaid balances over $\$ 300$ but under $\$ 1000$, and $15 \%$ on unpaid balances over $\$ 1000$. There is no maximum charge on other loans. There is no ceiling rate on either corporate loans or real estate investment trusts.

Consume loans other than supervised loans carry a maximum rate of $12 \%$. Whe maximum charge on supervised loans is $18 \%$ on the farst $\$ 1000$ and $14.45 \%$ on any additional. There is no ceiling on any other type of toon.

There is no cetling on foons over $\$ 25$
rate applies on toans to comporations.

Laans secured by real estate cary a maximum rate of $10 \%$. However, laans guaranteed by Federal agencies are exempt from the usury laws. Corporde loans moy be any rate.

No moximum rate applies if the loan is for nonpersonal or business purposes and the contract is in writing and involves more than $\$ 2000$.

No ceiling applies to bushess toans in excess of $\$ 5000$. Residential mortgage locth may be at $10 \%$.

No ceiling rate applies to corporate loans, realty secured loans, or federally or state approved loons. No centing rate is applted to locans in excess of $\$ 100,000$.

Corporations organized for profit may pay to $\frac{4}{2} 5 \%$ on loans in excess of $\$ 2500$.

Corporate loans may be at ony rate.

Corporate loans may be at any rate. The maximum rate is waived on certain loans by building and loan associations, installment loans, industrial loans, and personal loans by bank and trust companies or credit unions. 


\section{STATE USURY LAWS ${ }^{1}$ (Cont.)}

\begin{tabular}{|c|c|c|}
\hline State & Basic Rate & Some Maior Exceptions \\
\hline Nevada & $12 \%$ & \\
\hline New Hampshire & None & \\
\hline New Jersey & $8 \%$ & $\begin{array}{l}\text { The basic rate applies to loans under } \$ 50,000 \text {. Loans secured by sealty carry a maximum of } 83 \% \% \text {. } \\
\text { The rates are not applicable to loan contracts made by savings and loan campanies, banks, of any } \\
\text { department of Housing and Urban Affars or FHA approved loans purchesed by Federal government. }\end{array}$ \\
\hline New Mexico & $10 \%$ & A $12 \%$ ceiling applies to unsecured loans. \\
\hline New York & $83 \%$ & Demand notes of $\$ 5000$ or aver with collateral security may carry a rate of up to $25 \%$. \\
\hline North Carolina & $8 \%$ & $\begin{array}{l}\text { Celling rates on loans are graduated according to the size and purpose of the loans reaching } 12 \% \\
\text { on loons of } \$ 100,000 \text { and unlimited on loans of } \$ 300,000 \text { and larger. First mortgages on single } \\
\text { fomily dwellings moy be contracted for in writing at any rate ogreed upon by the partites. Corparations } \\
\text { may pay any fote. }\end{array}$ \\
\hline
\end{tabular}

North Dakoto

Ohio

Oklahoma

Oregon

Penrsylvania

Rhode Island

South Caroline

South Dakoto

$10 \%$

Tennessee

$10 \%$

Texas

$10 \%$

Utoh

$18 \%$

Vermont

Virginia $8 \%$

Wostington

$12 \%$

West Virginia

Wisconsin

Wyoming
The maximum rate on laans of from $\$ 50,000$ to $\$ 100,000$ is $10 \%$ and on loans between $\$ 100,000$ and $\$ 500,000,12 \%$. Lans larger than $\$ 500,000$ may be at any rate. First morkgage red estate loans made by savings and loan companies, the Department of Housing \& UFban Affairs or FHA approyed mortgages are exempt. any rate. Loans in excess of $\$ 100,000$ may be at any rafe.

Oklahoma's Uniform Consumer Credit Code allows $18 \%$ to supervised lenders and $10 \%$ to others lending to consumers. There is no ceiling rate on ofher types of loans. $\$ 50,000$ is $12 \%$ for corporations and $10 \%$ for individuals and non-profil organizations.

The maximum rate does not apply to loans of more than $\$ 50,000$, loans of $\$ 50,000$ or less secured by a hen upon real property; loans to business corporations; unsecured, non-colateralized loars in excess of $\$ 35,000$; and business loans in excess of $\$ 10,000$. The inferest rate on residential mortgages of an original principal of $\$ 50,000$ or less is a fluetuating administered rate. Far July 1974 this rate was sel of $9.5 \%$.

Corporate loans may carry any rafe. However, the maximum rate on all loans on real estate regardless of borrower is $10 \%$. Act or to instalifnent loons of banks and frust companies and building and loon associations on which interest is deducted in advonce and added to the principal.

Corporate loans above $\$ 5000$ have an $18 \%$ ceiling,

Revolving loans and non-supervised consumer loans carry a maximum rate of $18 \%$. Supervised loans carry a maximum rate of $18 \%$ on all unpaid balances, or a total of $36 \%$ on unpaid balances of $\$ 390$ or less; $21 \%$ on unpaid balances over $\$ 390$ and not over $\$ 1300$. All other loans may be made at any rate.

$8 \frac{1}{2} \%$ No celling rate applies to loans for income producing business or activity. Loons to finance real estate which is to be used as a primary residence or for agriculfure is subject to the contract rafe. However, logns to finance real estafe improvements or a second residence may be al any rate.

Any rate may apply to non-agricultural loans secured by a first mortgage or realty.

Corporate loans may be at any rate.

Revolving loans and consumer loans other than supervised loans may carry a maximum rate of $10 \%$, Supervised loans may be af a rate of the greater of $18 \%$ on all unpaid balances of $\$ 300$ or less, $21 \%$ on unpaid balances over $\$ 300$ and not over $\$ 1000$, and $15 \%$ on unpaid balances over $\$ 1000$. All other loans may be at any rate.

This table presents a synopsis of the maze of laws conceming usury in effect in the various states and the District of Cofumbia as of mid-July 1974 . Due to the complex nature of this area of the law, the table may not be ompletely accurate with respect to certain specific technical provisions. It should, however, allow the reader at least an gpportunity to gain some conception of the wide range of opinion concerning interest rate regulation by virtale of the greet

It might also be noted that mationat banks are permitted to charge 1 percentage point move than their Federal Reserve Bank's discount rate. At presefit tational banks may charge ateast 9 pereent on loas even in states with lower usury ceilings since the diseount rate is 8 percent.

2The bastc contract rate for loans in this state not involving real estate is 4 percentage points above the Federal Reserve discount rate at the 12th district heserve bank prevaling on the first day of the month preceding the commercement of the calendar quarter. tor teas estate contracts or commitments is $11 / 2 \%$ above the Feder

Where the parties agree in writing, interest may be charged and collected at a rate of up to $3 \%$ above the maximum bank deposit interest

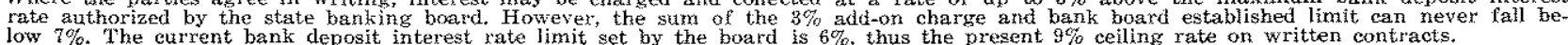


ceiling was sufficiently high so as not to impinge on market rates. As a result, the amount of new mortgage loans made on local properties declined markedly.

A number of District commercial banks and savings and loan associations have found that it has been more expedient to lend a greater share of their available funds in the unrestricted Federal funds market than to lend locally under oppressive ceilings. For example, on the April 24, 1974 call report, member banks in the Eighth District (outside eight large money market institutions) lent a net of $\$ 368$ million in Federal funds, at a time when the effective Federal funds rate was 10.3 percent. A year earlier, on the March 28, 1973 call date, when the Federal funds rate was 7.3 percent, these same banks advanced $\$ 283$ million in this market.

Available data also indicate that those who are not covered by usury restrictions are able to attract a larger share of available funds when market interest rates rise relative to effective rate ceilings for others. Eight large banks in the District advance credit to a great extent in national money markets where lending rates are virtually unregulated. Also, during the second quarter of this year, total deposits of the eight large District banks, bolstered by large CD purchases, rose at a 36 percent annual rate, while deposits at other member banks in the District increased at a 11.4 percent rate.

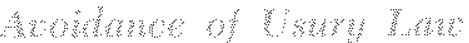

The impact of usury laws on credit markets has been made somewhat more tolerable by legal exceptions and other methods devised to soften the impact of the legislation. Without such exceptions it is conceivable that credit flows could virtually come to a halt in states like Missouri when the national rate on business loans with prime credit risk exceeds the 8 percent ceiling which prevails in this state.

In a number of jurisdictions small loan laws have been enacted which permit higher rates on certain small extensions of credit where operating costs are high and risk is frequently large. Many other legal exceptions have been granted for a variety of reasons. Retail credit charges, time-sales contracts, and loans to out-of-town residents are subject to higher ceilings in some states.

In Missouri, as in a number of other states, corporate businesses that are supposedly capable of protecting their interests in dealing with lenders are free to pay any rate that they desire. As might be expected, these corporations find that they have a tre- mendous advantage in attracting funds over unincorporated firms and individuals that are "protected" by the state.

In addition, many credit market arrangements have been devised for circumventing usury laws and permitting credit flows which otherwise would be halted. Some of these activities may be an outright violation of the law, such as simply ignoring the ceiling, or by calling the payment something other than interest. However, violation of usury laws frequently carries high financial penalties, such as loss of all interest or even principa; hence, lenders are generally reluctant to knowingly violate the statutes.

Other arrangements, which may or may not be technically legal, but which certainly conflict with the spirit of the law, have been adopted in order to effectively adjust a loan made at the legal rate to the market rate. One method is to lend to those who in some other way help you. Examples include the practice by lenders of favoring customers who maintain compensating deposit balances or whose firm does.

The effective rate on mortgages has traditionally been adjusted upward through the use of "points" charged either to the buyer, the seller, or both. At times, loans have been granted by third parties at the legal rate, after which the real lender then purchases the loan at a discount. Other loans have been "closed" in a more liberal location, such as across a state line. Such techniques, although permitting credit to flow, run risks of illegality, are inefficient, and probably cause effective rates to be slightly higher to the borrower and lower to the saver than they would be in a free market setting.

Lenders in states with low usury ceilings also have an option of moving funds into a state with more liberal laws. Comments from managers of funds indicate that the interstate movement of funds because of usury laws is sizable. Investment funds leave the state to finance mortgages in other states and to buy notes and bonds. Also, banks and savings and loan associations "sell" net sizable amounts of day-to-day Federal funds in the national money markets. This alternative of lending in another state protects large lenders to some extent and makes funds more readily available in states with liberal asury ceilings. However, such movements tend to be inefficient since credit is extended to less urgent projects and the cost of administering the loan is increased. Also, in the low ceiling state borrowers find credit still more difficult to obtain, lenders with small amounts are forced to accept lower yields, and economic activity suffers. 


\section{Conchasuras}

Ceilings on interest rates are relics of ancient and medieval thought, and have survived to the present largely because of a lack of confidence in market forces or because of a presumed benefit to higher credit risks. Actually, supply and demand for funds, rather than rate controls, have been the chief forces holding interest rates at existing levels.

Ceilings on rates may, at times, be of some benefit to borrowers easily deceived by unscrupulous lenders. However, usury laws cause a loss of individual freedom, and in modern economies they are disruptive, especially during periods of inflation when interest rates, like other prices, rise. Usury laws are based on false premises, operate perversely, and are economically inefficient. The cheap money which cannot be obtained is of little usefulness.
Effective usury ceilings, which alter the flow of funds, retard economic growth. The low maximums tend to prevent credit from flowing to higher risk individuals and businesses. Funds available are channelled into well-established, low- risk functions. As a result, innovation is discouraged, economic progress is slowed, and competition is reduced. The recognition that usury laws are burdensome, inequitable, and cause funds to leave the jurisdiction has led some states to relax the law.

Controls also adversely affect the saver, since they deny him the right to a competitive return on his funds. This is especially true of smaller savers. Those with large amounts of savings can more easily by-pass the controlled market by investing in uncontrolled central money and capital markets. Not only is the saver of moderate means injured, but the economy also loses as he becomes discouraged and saves less.

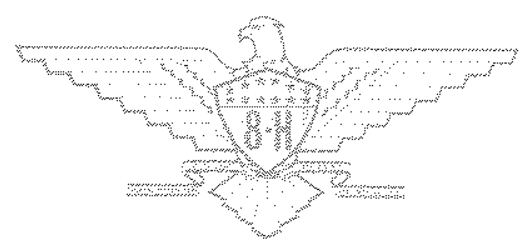

